\begin{tabular}{lccr} 
A R C H I E & O F & M E C H A N I C A L & E N G I N E E R I N G \\
\hline VOL. LXIII & 2016 & Number 1
\end{tabular}

10.1515/meceng-2016-0008

Key words: railway vehicle, flexible carbody, suspended equipment, vertical vibration, frequency response functions, geometric filtering effect

\title{
INFLUENCE OF SUSPENDED EQUIPMENT ON THE CARBODY VERTICAL VIBRATION BEHAVIOUR OF HIGH-SPEED RAILWAY VEHICLES
}

\begin{abstract}
The equipment mounted on the carbody chassis of the railway vehicles is a critical component of the vehicle in terms of ride comfort. The reason for that is their large mass, able to visibly influence the vibrations mode of the carbody. The paper examines the influence of the equipment upon the mode of vertical vibrations of the carbody in the high-speed vehicles, reached on the basis of the frequency response functions of the acceleration in three carbody reference points - at the centre and above the bogies. These functions are derived from the numerical simulations developed on a rigid-flexible coupled model, with seven degrees of freedom. As a rule, the results herein prove the influence of the equipment mounting mode (rigid or elastic), along with the speed regime, upon the level of vibrations in the carbody reference points, at the resonance frequency of the symmetrical bending mode. Similarly, it is also demonstrated how the equipment mass and the damping degree of the suspension system affect the level of the vibrations in the carbody.
\end{abstract}

\section{Introduction}

During running, the railway vehicle is subject to a permanent regime of vibrations, mainly coming from the vehicle-track interaction. As a rule, the track has irregularities due to the building imperfections, track exploitation, change in the track infrastructure as a result of the action of the environment factors or land movements [1]. Rolling on a track with irregularities triggers vibrations of the wheelsets that are further conveyed to the suspended masses of the vehicle, thus initiating and maintaining their vibrations [2].

While the general trend in the railway transportation is to increase velocities, there raises the issue of how to keep the same mode of vibrations at

* Department of Railway Vehicles, University Politehnica of Bucharest, Bucharest, Romania; E-mail: madalinadumitriu@yahoo.com 
a level required by the assurance of the dynamic performances in the vehicle - safety, ride quality and ride comfort.

A solution for reaching high velocities and also lowering the energy consumption has been identified in decreasing the weight of the vehicle carbody. The lighter the carbody, the higher its flexibility, which enables an easier excitation of the carbody structural vibrations [3, 4], while modifying the dynamic behaviour of the vehicle [5,6]. Even though the carbody structural vibrations are quite complex $[7,8]$, the largest influence on the vertical vibration regime of the vehicle is exerted by the carbody natural bending mode, with its natural frequency within the range between 7 and $12[\mathrm{~Hz}]$ [9], namely in an area where the human body is sensitive to vibrations [10, 11]. Under such conditions, the railway vehicles with light carbodies, rolling at high velocities, have an increased level of high-frequency vibrations, which significantly affects their ride comfort [12-14].

In the recent years, due to the requirement of designing light carbodies, the issue of vibrations regime in the high-speed electric multiple units (EMU) has become a regular concern in the research sector [15-17]. In order to increase the power of such vehicles, many devices have been mounted on the chassis of carbody, such as traction transformer, traction converter, air compressor, and so on. These devices can vary in their weight, from several tens of kilograms to tons, and bring in their own sources of vibrations.

It is known that most devices are elastically suspended from the carbody chassis so as to avoid the noise transmission and lower the level of carbody vibrations, thence the ride comfort is not influenced. In spite of the above, the identification of the best solution regarding the suspension of this equipment is a part of numerous studies [15-20]. As a general practice, the study of the vibration features of the carbody-equipment coupled system requires a vehicle model to include the flexible carbody, two bogies and four wheelsets, as well as an equipment that was modelled in an single-stage vibration isolation system and two-stage vibration isolation system. The analysis of the frequency response is carried out at the carbody centre while considering harmonic type in phase excitations on the four wheelsets of the vehicle, which however does not allow focusing on the influence of velocity and geometric filtering effect upon the vibrations mode in the carbody.

The article examines the influence of the suspended equipment upon the mode of vertical vibrations of the carbody in the high-speed vehicles, reached on the basis of the frequency response functions of the acceleration in three carbody reference points - at the centre and above the bogies. The vibrations are derived from the numerical simulations developed on a rigid-flexible coupled model, with seven degrees of freedom. The assumption is that the track vertical irregularities are in a harmonic shape and delayed against the 
axles, corresponding to the distances between them. As a rule, the results herein prove the influence of the equipment mounting mode (rigid or elastic), along with the speed regime and the position of the carbody reference point, upon the level of vibrations at the resonance frequency of the symmetrical bending mode. Likewise, there are mentioned observations related to the possibilities of lowering the level of vibrations at the resonance frequency of the first bending mode, by changing the equipment mass and of the damping degree of the suspension system.

\section{The vehicle mechanical model}

The mechanical model for the study of the vehicle vertical vibrations that includes the suspended equipment is featured in Fig. 1. It is about a rigid-flexible coupled model for a four-axle, two-level suspension vehicle, and running at a constant speed $V$ along a perfectly rigid track with vertical irregularities. Such irregularities that trigger movements of the suspended masses of the vehicle by means of the wheelsets are described by the functions $\eta_{j}$, with $j=1 \ldots 4$.

The model of the vehicle comprises a body with distributed parameters for the carbody and rigid bodies for the two bogies frames, four wheelsets and the suspended equipment. Such bodies are connected via Kelvin-Voigt systems, representing the suspension levels.

The carbody is represented by a free-free Euler-Bernoulli equivalent beam, of a constant cross-section and uniformly distributed mass. The beam parameters are defined as a function of the carbody parameters, thus: $L-$ length of the beam/carbody; $\rho_{c}=m_{c} / L$ - beam mass on a length unit, where $m_{c}$ represents the carbody mass; $\mu$ - structural damping coefficient; $E I-$ bending module, where $E$ is the longitudinal elastic module, and $I$ is the inertia moment of the beam cross-section.

There will be considered the carbody rigid modes of vibration - bounce $z_{c}$ and pitch $\theta_{c}$, and the first natural bending mode of the carbody in a vertical plan (the symmetrical bending). The carbody inertia reported to the vibration rigid modes is represented by mass $m_{c}$ and the mass moment of inertia $J_{c}$.

The carbody displacement $w(x, t)$ is the result of the overlap between the rigid vibration modes and the symmetrical bending

$$
w(x, t)=z_{c}(t)+\left(x-\frac{L}{2}\right) \theta_{c}(t)+X_{2}(x) T_{2}(t),
$$

where $x$ is the coordinate in relation to the carbody end, $T_{2}(t)$ is the time coordinate of the natural symmetrical bending mode in the carbody, while 


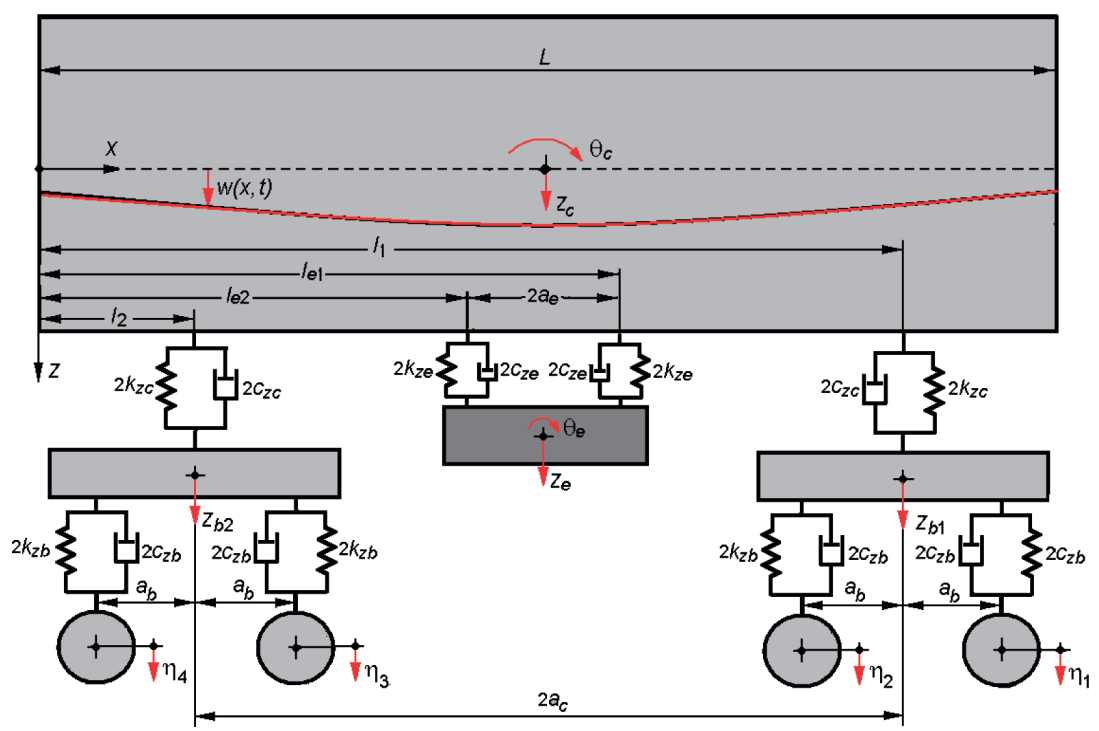

Fig. 1. The vehicle mechanical model

$X_{2}(x)$ represents the eigenfunction of the symmetrical bending mode given by the relation [21]

$$
X_{2}(x)=\sin \beta_{2} x+\sinh \beta_{2} x-\frac{\sin \beta_{2} L-\sinh \beta_{2} L}{\cos \beta_{2} L-\cosh \beta_{2} L}\left(\cos \beta_{2} x+\cosh \beta_{2} x\right)
$$

with

$$
\beta_{2}=\sqrt[4]{\omega_{2}^{2} \rho_{c} /(E I)} \text { and } \cos \beta_{2} L \cosh \beta_{2} L-1=0
$$

where $\omega_{2}$ is the natural angular frequency of the first bending mode.

For each bogie, with the mass $m_{b}$ and the mass moment of inertia $J_{b}$, there is only one vibration mode, namely the bounce $z_{b i}$, with $i=1,2$. The bogie pitch motion is overlooked, as it is independent from the vertical movement of the vehicle carbody.

The elastic and damping elements of the secondary suspension of each bogie have the elastic constant $2 k_{z c}$, and damping constant $2 c_{z c}$. The primary suspension corresponding to an axle has an elastic constant $2 k_{z b}$ and damping constant $2 c_{z b}$.

The suspended equipment of a mass $m_{e}$ and mass moment of inertia $J_{e}$ makes a translation movement on a vertical direction $z_{e}$ and a rotation movement in a vertical plan $\theta_{e}$. This is connected to the carbody via two Kelvin-Voigt systems, each of them having the elastic constant $2 k_{z e}$ and damping constant $2 c_{z e}$. 


\section{The movement equations of the vehicle and suspended equipment}

The movement equation of the carbody writes as below

$E I \frac{\partial^{4} w(x, t)}{\partial x^{4}}+\mu I \frac{\partial^{5} w(x, t)}{\partial x^{4} \partial t}+\rho_{c} \frac{\partial^{2} w(x, t)}{\partial t^{2}}=\sum_{i=1}^{2} F_{z c i} \delta\left(x-l_{i}\right)+\sum_{i=1}^{2} F_{z e i} \delta\left(x-l_{e i}\right)$

where $\delta(x)$ is Dirac delta function, the distances $l_{i}$ fix the position of the carbody bearing points on the secondary suspension and the distances $l_{e i}$ give the position of the clamping points for the suspended equipment from the vehicle carbody; $F_{z c i}$ represents the forces due to the secondary suspension corresponding to the bogie $i$, while $F_{z e i}$ stands for the forces derived from the elastic clamping system of the suspended equipment

$$
\begin{gathered}
F_{z c i}=-2 c_{z c}\left(\frac{\partial w\left(l_{i}, t\right)}{\partial t}-\dot{z}_{b i}\right)-2 k_{z c}\left(w\left(l_{i}, t\right)-z_{b i}\right) \\
F_{z e i}=-2 c_{z e}\left[\frac{\partial w\left(l_{e i}, t\right)}{\partial t}-\left(\dot{z}_{e} \pm a_{e} \dot{\theta}_{e}\right)\right]-2 k_{z e}\left[w\left(l_{i e}, t\right)-\left(z_{e} \pm a_{e} \theta_{e}\right)\right]
\end{gathered}
$$

where $2 a_{e}$ is the distance between the clamping points of the suspended equipment from the carbody.

When implementing the method of the modal analysis and considering the orthogonality of the eigenfunction of the carbody bending mode, the equation of motion (4) is changed into three second-order ordinary differential equations describing the bounce, pitch motions and symmetrical bending of the carbody:

$$
\begin{gathered}
m_{c} \ddot{z}_{c}=\sum_{i=1}^{2} F_{z c i}+\sum_{i=1}^{2} F_{z e i} ; \\
J_{c} \ddot{\theta}_{c}=\sum_{i=1}^{2} F_{z c i}\left(l_{i}-\frac{L}{2}\right)+\sum_{i=1}^{2} F_{z e i}\left(l_{e i}-\frac{L}{2}\right) ; \\
m_{m 2} \ddot{T}_{2}+c_{m 2} \dot{T}_{2}+k_{m 2} T_{2}=\sum_{i=1}^{2} F_{z c i} X_{2}\left(l_{i}\right)+\sum_{i=1}^{2} F_{z e i} X_{2}\left(l_{e i}\right) ;
\end{gathered}
$$

with

$$
k_{m 2}=E I \int_{0}^{L}\left(\frac{\mathrm{d}^{2} X_{2}}{\mathrm{~d} x^{2}}\right)^{2} \mathrm{~d} x ; \quad c_{m 2}=\mu I \int_{0}^{L}\left(\frac{\mathrm{d}^{2} X_{2}}{\mathrm{~d} x^{2}}\right)^{2} \mathrm{~d} x ; \quad m_{m 2}=\rho_{c} \int_{0}^{L} X_{2}^{2} \mathrm{~d} x .
$$


The equations defining the bounce motions of the bogies are

$$
\begin{aligned}
& m_{b} \ddot{z}_{b 1}=\sum_{j=1}^{2} F_{z b j}-F_{z c 1} ; \\
& m_{b} \ddot{z}_{b 2}=\sum_{j=3}^{4} F_{z b j}-F_{z c 2},
\end{aligned}
$$

where $F_{z b j}$ represent the forces due to the primary suspension corresponding to the wheelset $j$, namely

$$
\begin{aligned}
& F_{z b 1,2}=-2 c_{z b}\left(\dot{z}_{b 1} \pm a_{b} \dot{\theta}_{b 1}-\dot{\eta}_{1,2}\right)-2 k_{z b}\left(z_{b 1} \pm a_{b} \theta_{b 1}-\eta_{1,2}\right) ; \\
& F_{z b 3,4}=-2 c_{z b}\left(\dot{z}_{b 2} \pm a_{b} \dot{\theta}_{b 2}-\dot{\eta}_{3,4}\right)-2 k_{z b}\left(z_{b 2} \pm a_{b} \theta_{b 2}-\eta_{3,4}\right),
\end{aligned}
$$

in which $2 a_{b}$ is the bogie wheelbase.

The bounce and pitch motions of the suspended equipment are included in the equations

$$
\begin{gathered}
m_{e} \ddot{z}_{e}=-\sum_{i=1}^{2} F_{z e i} ; \\
J_{e} \ddot{\theta}_{e}=-\sum_{i=1}^{2} F_{z e i}\left(l_{e i}-\frac{L}{2}\right) .
\end{gathered}
$$

The equations of motion above will be featured in the following section in order to calculate the frequency response functions of the vehicle.

\section{The frequency response functions of the vehicle}

Further on, the track vertical irregularities are considered to have a harmonic shape with the wavelength $\Lambda$ and amplitude $\eta_{0}$ and delayed against the wheelsets corresponding to the distances between them $\left(2 a_{c}-\right.$ carbody wheelbase and $2 a_{b}$ - bogie wheelbase). Therefore, the functions $\eta_{j}$ describing the track irregularities against the four wheelsets write as such

$$
\eta_{1,2}\left(x_{c}\right)=\eta_{0} \cos \frac{2 \pi}{\Lambda}\left(x_{c}+a_{c} \pm a_{b}\right) ; \quad \eta_{3,4}\left(x_{c}\right)=\eta_{0} \cos \frac{2 \pi}{\Lambda}\left(x_{c}-a_{c} \mp a_{b}\right),
$$

where $x_{c}$ stands for the coordinate of the carbody centre.

While considering $x_{c}=V t$, the functions $\eta_{j}$ can be also expressed as time harmonic functions, namely

$$
\eta_{1,2}(t)=\eta_{0} \cos \omega\left(t+\frac{a_{c} \pm a_{b}}{V}\right) ; \quad \eta_{3,4}(t)=\eta_{0} \cos \omega\left(t-\frac{a_{c} \mp a_{b}}{V}\right),
$$


where $\omega=2 \pi V / \Lambda$ represents the angular frequency induced by the track excitation, while the related frequency is $f=V / \Lambda$.

As for the vehicle response, it is assumed that this is harmonic too, with a similar frequency with the one induced by the track excitation. The coordinates for the vehicle motions and of the suspended equipment are written as

$$
p_{k}(t)=P_{k} \cos \left(\omega t+\varphi_{k}\right) \text {, with } k=1 \div 7 \text {, }
$$

where $p_{1}=z_{c}, p_{2}=\theta_{c}, p_{3}=T_{2}, p_{4}=z_{b 1}, p_{5}=z_{b 2}, p_{6}=z_{e}$ and $p_{7}=\theta_{e}$; $P_{k}$ stand for the amplitudes corresponding to the motions of the vehicle suspended masses; $\varphi_{k}$ is the phase of coordinate $k$ in respect to the track vertical irregularities against the vehicle centre. duced:

The complex quantities associated with the real ones are further intro-

- for the track vertical irregularities against the wheelsets

$$
\bar{\eta}_{j}(t)=\bar{\eta}_{j} e^{\mathrm{i} \omega t} ;
$$

- for the coordinates of the vehicle motions

$$
\bar{p}_{k}(t)=\bar{P}_{k} e^{\mathrm{i} \omega t},
$$

where the complex amplitudes in the track irregularities against the wheelsets write as below

$$
\bar{\eta}_{1,2}=\eta_{0} e^{\mathrm{i} \omega\left(t+\frac{a_{c} \pm a_{b}}{V}\right)} ; \quad \bar{\eta}_{3,4}=\eta_{0} e^{\mathrm{i} \omega\left(t-\frac{a_{c} \mp a_{b}}{V}\right)},
$$

and the amplitude of the coordinate $k$ is

$$
\bar{P}_{k}=P_{k} e^{\mathrm{i} \phi_{k}} .
$$

When introducing the complex quantities (20-21) in the equations of motion (7-9, 11-12 and 15-16), the result is a set of linear nonhomogeneous algebraic equations, with variables in the complex amplitudes $\bar{P}_{k}$ of the coordinates in the vehicle motions and of the suspended equipment, which can be written under a matrix form

$$
\mathbf{X} \overline{\mathbf{P}}=\overline{\mathbf{Y}},
$$

where $\overline{\mathbf{P}}$ is the vector of the complex amplitudes of the coordinates in the vehicle motions, $\mathbf{X}$ - the system matrix, and $\mathbf{Y}$ - the vector of the nonhomogeneous terms of excitation.

Solving this set of equations allows the determination of the frequency response functions in the vehicle to the excitations derived from the track vertical irregularities. Thus, the response function of the carbody movement 
in a particular point of abscissa $x$ (for $0 \leq x \leq L$ ) corresponding to the angular frequency $\omega$ is as below

$$
\bar{H}_{c}(x, \omega)=\bar{H}_{z_{c}}(\omega)+(L / 2-x) \bar{H}_{\theta_{c}}(\omega)+X_{2}(x) \bar{H}_{T_{2}}(\omega),
$$

where $\bar{H}_{z_{c}}(\omega), \bar{H}_{\theta_{c}}(\omega), \bar{H}_{T_{2}}(\omega)$ are the response functions for the carbody vibration modes - bounce $\left(z_{c}\right)$, pitch $\left(\theta_{c}\right)$ and the symmetrical bending $\left(T_{2}\right)$, calculated by the following equations

$$
\bar{H}_{z_{c}}(\omega)=\frac{\bar{P}_{1}}{\bar{\eta}_{0}} ; \quad \bar{H}_{\theta_{c}}(\omega)=\frac{\bar{P}_{2}}{\bar{\eta}_{0}} ; \quad \bar{H}_{T_{2}}(\omega)=\frac{\bar{P}_{3}}{\bar{\eta}_{0}},
$$

where $\bar{\eta}_{0}=\eta_{0} e^{\mathrm{i} 0}$.

The equation (25) can be customized for the three reference points of the carbody at its centre and above the two bogies. In this manner, the response function of the movement at the carbody centre is

$$
\bar{H}_{c m}(\omega)=\bar{H}_{c}(L / 2, \omega)=\bar{H}_{z_{c}}(\omega)+X_{2}(L / 2) \bar{H}_{T_{2}}(\omega),
$$

and above the two bogies

$$
\bar{H}_{c b 1,2}(\omega)=\bar{H}_{c}\left(l_{1,2}, \omega\right)=\bar{H}_{z_{c}}(\omega) \pm a_{c} \bar{H}_{\theta_{c}}(\omega)+X_{2}\left(l_{1,2}\right) \bar{H}_{T_{2}}(\omega) \text {. }
$$

The response function of the movement helps us to calculate the response function of the carbody acceleration

$$
\bar{H}_{a c}(x, \omega)=\omega^{2} \bar{H}_{c}(x, \omega) .
$$

While taking into account the response functions defined in (27) and (28), the response functions for the vertical acceleration in the carbody reference points can be now estimated.

As shown later, a series of basic properties of the regime of vertical vibrations in the vehicle carbody will be highlighted starting from the frequency response functions.

\section{The numerical analysis of the regime of vibrations in the vehicle carbody}

This section features the vibration regime of the vehicle carbody, based on its frequency response calculated in three reference points. The parameters of the numerical model are shown in Table 1 and their values are typical for a high speed railway vehicle $[15,16]$. 
INFLUENCE OF SUSPENDED EQUIPMENT ON THE CARBODY VERTICAL VIBRATION BEHAVIOUR. . 153

Table 1.

The parameters of the vehicle's numerical model

\begin{tabular}{|l|l|}
\hline$m_{c}=28800 \mathrm{~kg}$ & $2 k_{z c}=1.11 \mathrm{MN} / \mathrm{m}$ \\
\hline$m_{b}=2600 \mathrm{~kg}$ & $2 c_{z c}=30.40 \mathrm{kNs} / \mathrm{m}$ \\
\hline$m_{e}=4000 \mathrm{~kg}$ & $4 k_{z b}=3.695 \mathrm{MN} / \mathrm{m}$ \\
\hline$J_{c}=1411200 \mathrm{~kg} \cdot \mathrm{m}^{2}$ & $4 c_{z b}=43.12 \mathrm{kNs} / \mathrm{m}$ \\
\hline$J_{b}=1400 \mathrm{~kg} \cdot \mathrm{m}^{2}$ & $2 k_{z e}=5.05 \mathrm{MN} / \mathrm{m}$ \\
\hline$J_{e}=2250 \mathrm{~kg} \cdot \mathrm{m}^{2}$ & $2 c_{z e}=50.26 \mathrm{kNs} / \mathrm{m}$ \\
\hline$L=24.5 \mathrm{~m}$ & $E I=3.392 \cdot 10^{9} \mathrm{Nm}$ \\
\hline $2 a_{c}=17.5 \mathrm{~m} ; 2 a_{b}=2.5 \mathrm{~m}$ & $2 a_{e}=1.5 \mathrm{~m}$ \\
\hline
\end{tabular}

During a first stage, the harmonic movements of the four wheelsets are considered to be in phase and the response functions of the carbody acceleration are calculated at its centre and above the bogies, as in Fig. 2. Three distinct situations have been considered: a model with no suspended equipment; rigid fixed equipment; elastically suspended equipment. What can be noticed in both diagrams is the peak of the resonance frequency of the carbody bounce motion that is also visible at $1.14 \mathrm{~Hz}$, irrespective of the circumstances. Similarly, the resonance frequency of the carbody bending modifies, due to the existence of the suspended equipment and how it is fixed to the carbody. For instance, this frequency shows at $10 \mathrm{~Hz}$ for the model with no suspended equipment and it lowers to $9.3 \mathrm{~Hz}$, should the equipment is rigidly fixed to the carbody. In the case of the elastically fixed equipment, there are two peaks matching the resonance frequencies of the carbody-equipment coupled system, at $7.64 \mathrm{~Hz}$ and $11.44 \mathrm{~Hz}$. The 'low'
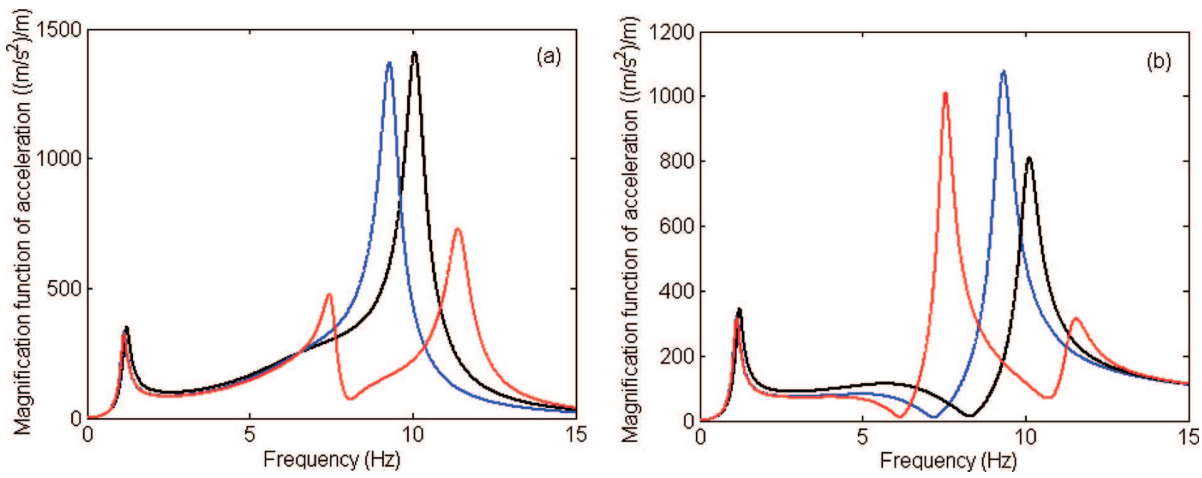

Fig. 2. Response function of the carbody acceleration: a) at carbody centre; b) above the bogies: no equipment; — rigid fixed equipment; — elastically suspended equipment 
frequency of $7.64 \mathrm{~Hz}$ corresponds to the in-phase vibration of the carbody and equipment, whereas the 'high' frequency of 11.44 is for the anti-phase vibration of the carbody and equipment.

The level of vibrations in the carbody changes at the bending resonance frequency when introducing the suspended equipment in the model of the vehicle. The rigid fixation of the equipment to the carbody leads to the decrease in the response function of the acceleration at the centre of carbody and to its increase above the bogies. Should the equipment be elastically suspended, the level of vibrations at the carbody centre visibly reduces for both resonance frequencies of the bending. An increase in the response frequency will show instead above the bogies for the 'low' bending frequency, compared to the response function at the bending frequency of the carbody with no suspended equipment.

Further on, the vertical movements of the four vehicle wheelsets are out of phase among them in correspondence with the distances between them, $2 a_{c}$ and $2 a_{b}$, respectively.

The result of the difference of phase between the vertical movements of the wheelsets will be the so-called geometric filtering effect of the excitations induced by the track vertical irregularities. The effect comes from the distances between the wheelsets (the bogie wheelbase and the carbody wheelbase) and is influenced by the velocity, as being an important feature of the regime of vertical vibrations in the railway vehicle. As a rule, the geometric filtering effect is exclusively due to the manner in which the track excitations are conveyed to the suspended masses of the vehicle via the wheelsets, irrespective of the features of the suspension [22, 23].

As seen in Fig. 3, a succession of maximum and minimum values is evident in the vehicle response, due to the geometric filtering effect. The maximum values of the response function in the carbody acceleration correspond to the times when the geometric filtering is not operational, while the minimum values show as anti-resonance frequencies and coincide with the geometric filtering frequencies in the vertical movements of the wheelsets. It can be noticed that the geometric filtering effect better manifests at a speed of $250 \mathrm{~km} / \mathrm{h}$. The geometric filtering effect has indeed a selective nature depending on the velocity regime - in other words, the lower velocity, the more efficient the effect (i.e. it features more anti-resonance frequencies). As a speed function, the anti-resonance frequencies can reach a point to coincide with the frequency of one of the natural vibration modes of the vehicle, when its influence is diminished a great deal, which explains why the vibrations regime of the vehicle does not increase along with the velocity [21, 22] This fact is noticeable in the diagrams of Fig. 3, where the level of vibrations in the carbody at the resonance frequency of bending 

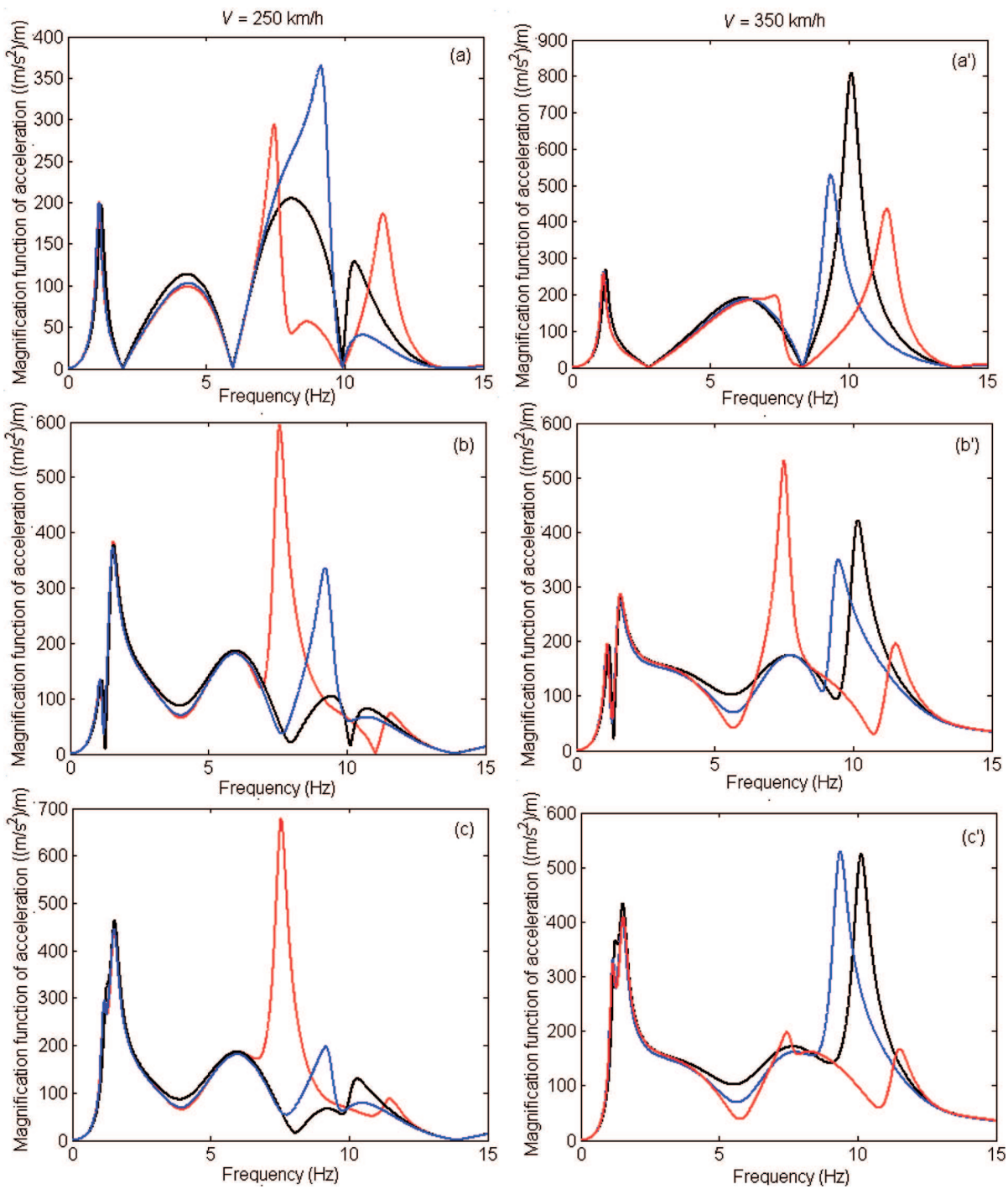

Fig. 3. Response function of the carbody acceleration: a) and a') at carbody centre; b) and b') above the front bogie; c) and c') above the rear bogie:

— no equipment; — rigid fixed equipment; — elastically suspended equipment

changes very much in dependence on velocity for all three cases - a model with no suspended equipment; rigid fixed equipment; elastically suspended equipment.

In comparison with the previous situation (see Fig. 2), the velocity should be taken into account in order to establish the conditions in which the manner of attaching the suspended equipment contributes to the decrease in the level of vibrations of the carbody at the resonance frequency of bending. For 
instance, should the level of vibrations corresponding to the no-equipment model be looked at as a reference point, this level will increase at $250 \mathrm{~km} / \mathrm{h}$ and decrease at $350 \mathrm{~km} / \mathrm{h}$ at the carbody centre, due to the rigid attachment of the equipment. On the other hand, if the equipment is elastically suspended, the level of vibrations at the carbody centre goes up at $250 \mathrm{~km} / \mathrm{h}$ and down at $350 \mathrm{~km} / \mathrm{h}$, for both resonance frequencies of bending.

Figure 4 features the response functions of the carbody acceleration in its reference points at the resonance frequencies of bending: $10 \mathrm{~Hz}-$ no equipment; $9.3 \mathrm{~Hz}$ - rigid fixed equipment; $7.64 \mathrm{~Hz}$ and $11.44 \mathrm{~Hz}$ - elastically suspended equipment. There are hence highlighted the velocities at which the influence of bending upon the vibrations regime of carbody is visibly diminished, due to the geometric filtering effect. In actual fact, it is about the velocities at which the geometric filtering frequencies coincide with the natural frequencies of the carbody bending. The geometric filtering effect can be noticed to have a selective nature, due to the velocity, being more visible at low speeds of up to circa $150 \mathrm{~km} / \mathrm{h}$. The higher the speed, the smaller the influence of the geometric filtering effect.
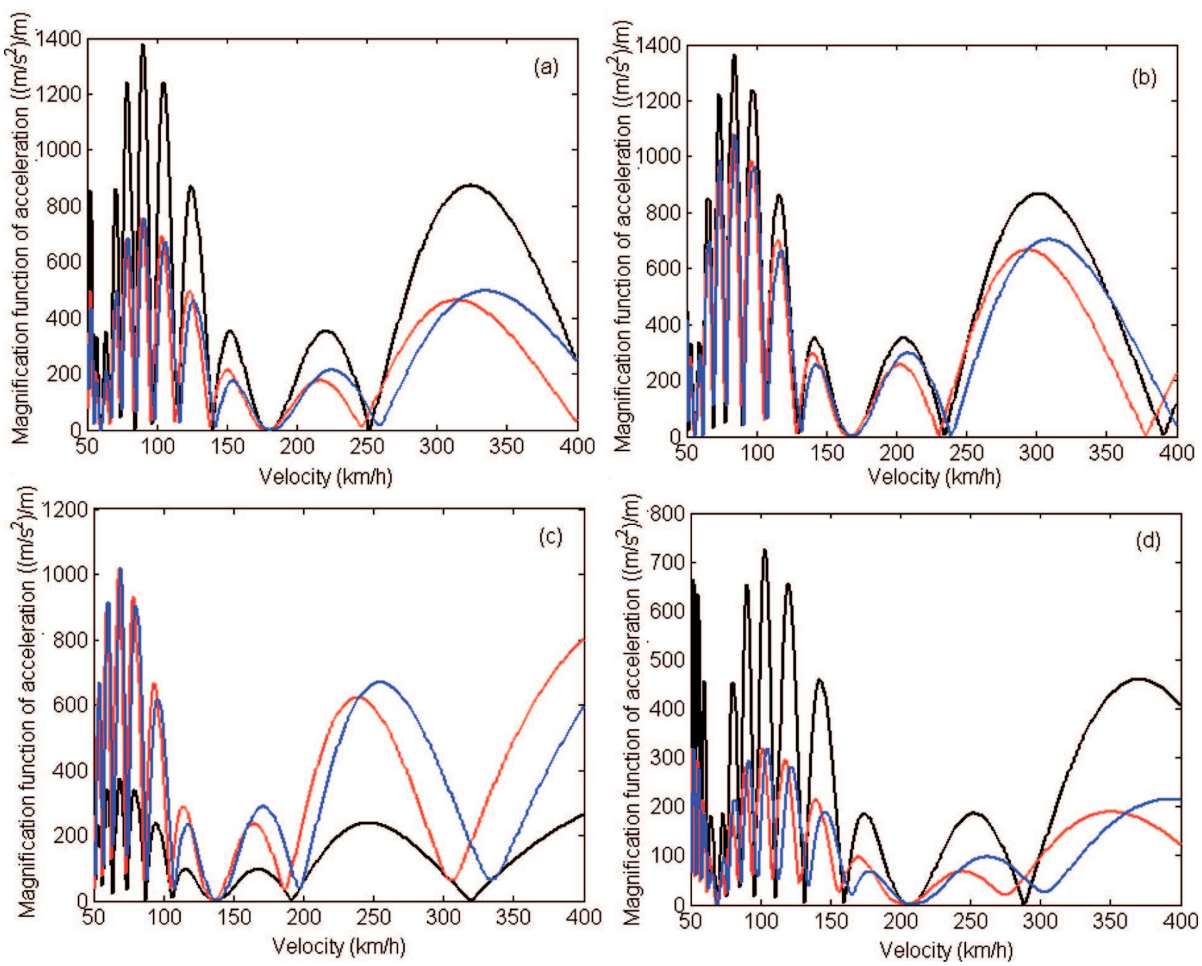

Fig. 4. Response function of the carbody acceleration at the resonance frequencies of the carbody bending: a) $10 \mathrm{~Hz}$ - no equipment; b) $9.3 \mathrm{~Hz}$ - rigid fixed equipment; c) $7.64 \mathrm{~Hz}$ and d) 11.44 $\mathrm{Hz}$ - elastically suspended equipment:

— at carbody centre; — above the front bogie; _ _ above the rear bogie 
Another issue to be looked at in the diagrams of Fig. 4 is linked to the level of vibrations in the carbody, due to its bending in the three reference points. For the no-equipment model and for the rigid fixed equipment, the level of vibrations coming from bending is higher at the carbody centre than above the bogies, irrespective of velocity. When the equipment is elastically suspended, the level of vibrations at the low bending frequency is much reduced at the carbody centre versus above the bogies. On the contrary, for a high bending frequency, the level of bending-derived vibrations at the carbody centre goes up along with the level in the reference points above the bogies.

Further on, the frequency response of the carbody acceleration will be examined, considering that the equipment is elastically suspended.

The diagrams in Fig. 5 emphasize the influence of the velocity upon the response function of acceleration calculated at the carbody centre and above the bogies. The regime of vibrations changes significantly when velocity increases in all the reference points of the carbody. Instance the case of the peaks of the response function corresponding to the resonance frequencies of the dominant vibration modes of the carbody - bounce (at $1.14 \mathrm{~Hz}$ ), pitch $(1.52 \mathrm{~Hz}$ ) and bending (at $7.64 \mathrm{~Hz}$ and $11.44 \mathrm{~Hz}$ ), whose values are represented in the diagrams in Fig. 6. As seen above, the regime of vibrations will not continually intensify along with the increase in velocity, due to the geometric filtering effect.

Moreover, it is evident that the vibration modes dominating the carbody response are changed, depending on velocity. For instance, the carbody response is roughly constant for all three resonance frequencies at speed $250 \mathrm{~km} / \mathrm{h}$, whereas this response is dominated by the bending corresponding to the 'high' frequencies at $150 \mathrm{~km} / \mathrm{h}$ and $350 \mathrm{~km} / \mathrm{h}$. In the carbody reference points above the bogies, its response is dominated by pitch at $150 \mathrm{~km} / \mathrm{h}$ and by bending at 'low' frequency for $250 \mathrm{~km} / \mathrm{h}$. At $350 \mathrm{~km} / \mathrm{h}$, above the front bogie, the carbody response is dominated by bending at 'low' frequency and by its pitch above the rear bogie.

Figure 7 features the response function of acceleration calculated at speed $350 \mathrm{~km} / \mathrm{h}$ in the carbody reference points for various values of the mass in the suspended equipment. The change in the equipment mass mainly influence the vibrations regime of carbody at the resonance frequencies of bending. The increase in the equipment mass hence leads to a similar action for the level of vibrations, both at its centre and above the two bogies, at the 'low' frequency of the carbody bending. Alternatively, this level of vibrations lowers when the mass of the suspended equipment increases, at the 'high' bending frequency. Similarly, the expansion of the frequency range between the carbody bending resonances is distinct, along with higher equipment mass. 

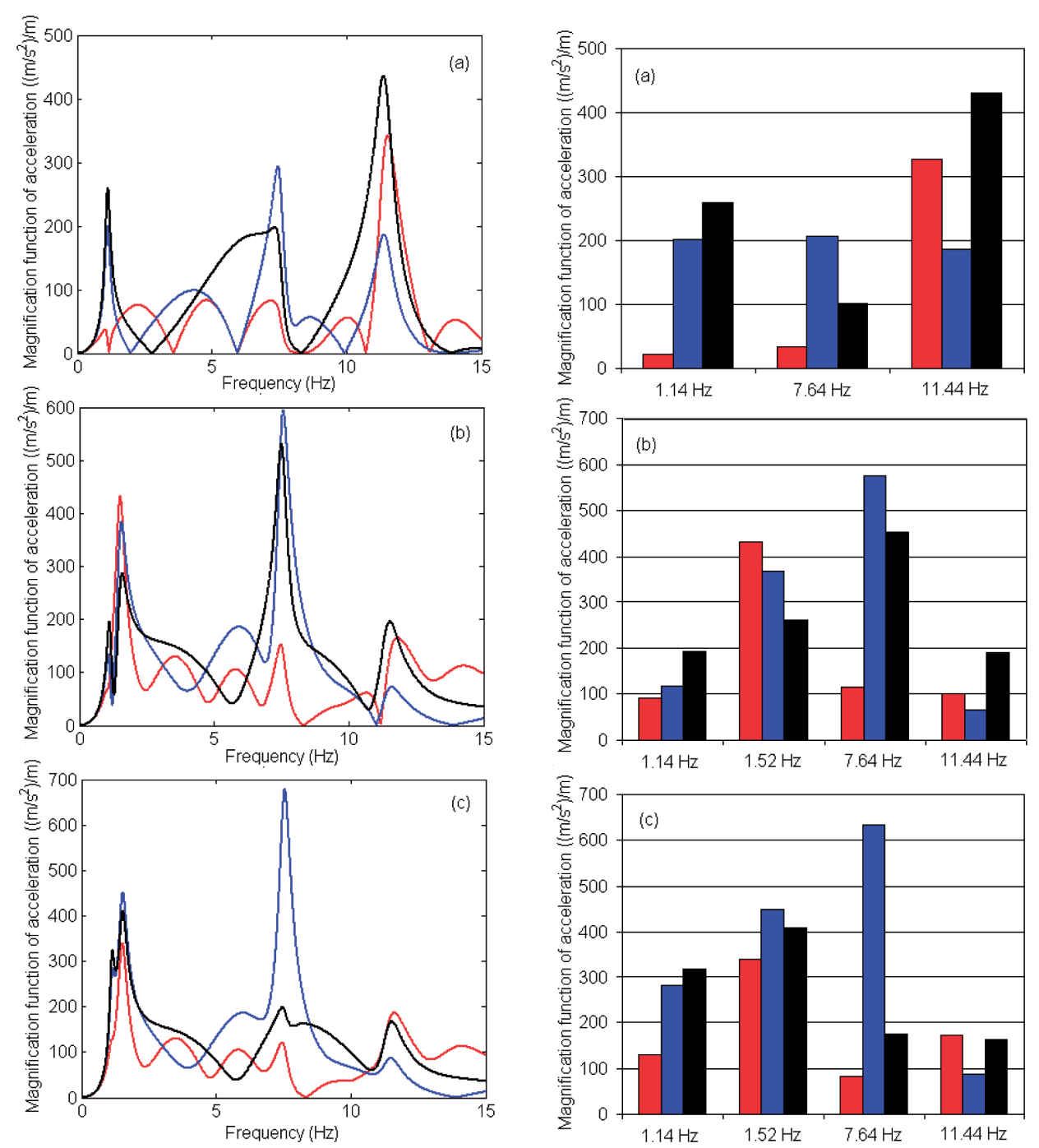

Fig. 5. Influence of the velocity on the carbody response function: a) at carbody centre; b) above the front bogie; c) above the rear bogie: -150 $\mathrm{km} / \mathrm{h} ;-250 \mathrm{~km} / \mathrm{h} ;-350 \mathrm{~km} / \mathrm{h}$

Fig. 6. Carbody response function at the resonance frequencies: a) at carbody centre; b) above the front bogie; c) above the rear bogie: $150 \mathrm{~km} / \mathrm{h} ; \square 250 \mathrm{~km} / \mathrm{h} ; \quad 350 \mathrm{~km} / \mathrm{h}$

In order to examine the influence of the parameters of the coupling system of the suspended equipment upon the carbody regime of vibrations, the damping degree of this system is introduced, as follows

$$
\zeta_{z e}=\frac{4 c_{z e}}{2 \sqrt{4 k_{z e} m_{e}}} .
$$



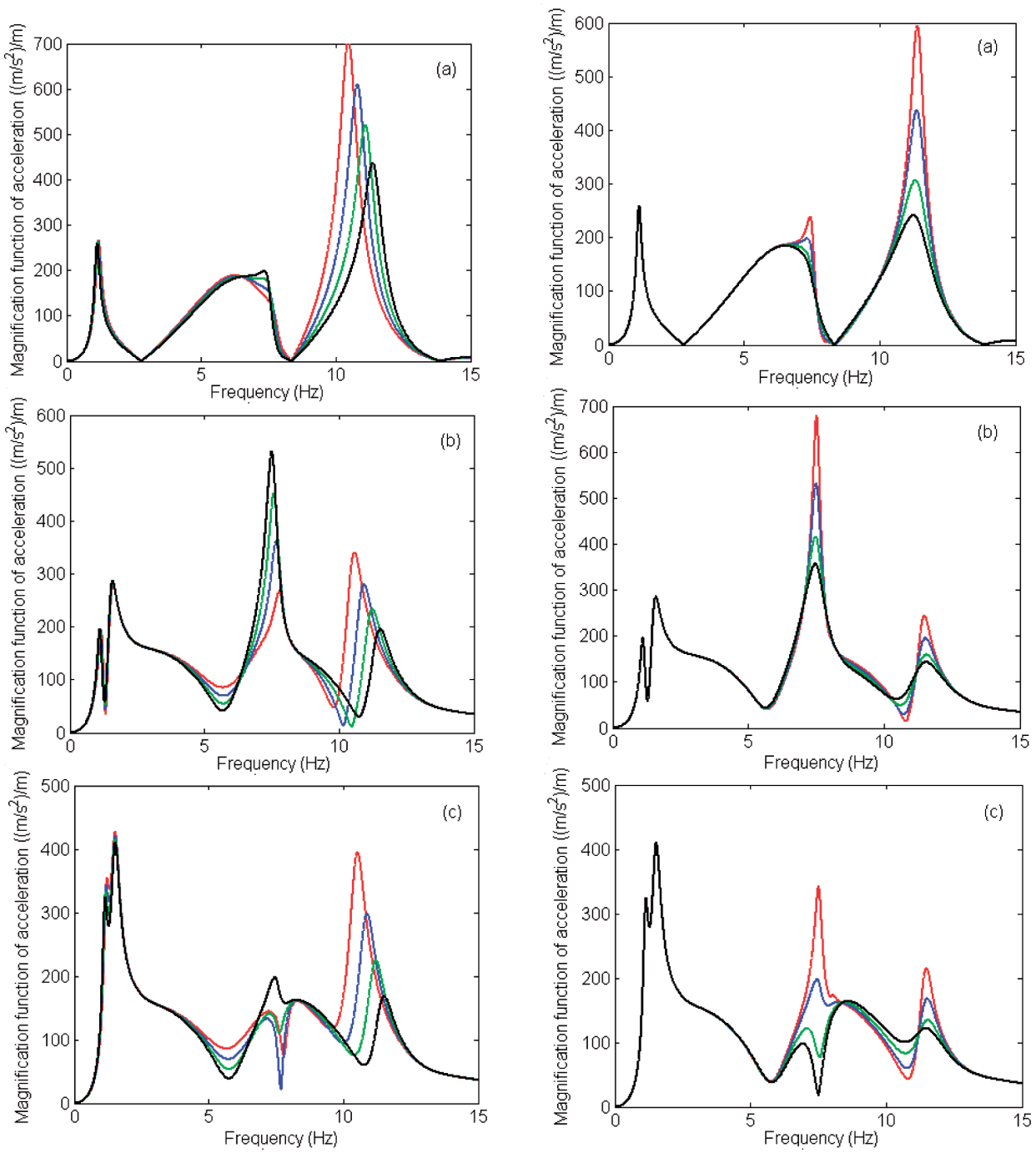

Fig. 7. Influence of the equipment mass on the carbody response function: a) at carbody centre; b) above the front bogie; c) above the rear bogie: $-1000 \mathrm{~kg}$; $-2000 \mathrm{~kg}$; $-3000 \mathrm{~kg}$; $-4000 \mathrm{~kg}$

Fig. 8. Influence of the damping ratio of the equipment on the carbody response function: a) at carbody centre; b) above the front bogie; c) above the rear bogie: $-0.01 ;-0.025$; $-0.05 ;-0.075$

As seen in the diagrams in Fig. 8, an increase in $\zeta_{z e}$, the level of carbody vibrations goes down for both resonance frequencies of bending, an observation valid for all three reference points of the carbody. 


\section{Conclusions}

The mounting of the equipment onto the chassis of the high-speed vehicles carbody can influence the regime of the vertical vibrations of the carbody, due to its large masses. The paper reviews this issue, based on the frequency response functions of the carbody acceleration in its three reference points - at carbody centre and above the bogies. Within the results derived from numerical simulations, the examination lies on the equipment influence and its manner of attachment (rigid or elastic), correlated with the velocity regime and mainly the position of the carbody reference point, upon the level of vibrations at the resonance frequency of the symmetrical bending.

It has been shown that the natural frequency of the first carbody bending changes, due to the equipment and the manner of its attachment to the carbody (rigid or elastic). For an elastic suspension, there are two resonance frequencies, namely a 'low' frequency corresponding to the in-phase vibration of the equipment and carbody, and a 'high' frequency coinciding with the anti-phase vibration of the equipment and carbody.

It is essential to take into account that the displacements of the wheelsets are delayed in correspondence with the distances between them, so as to help with examining the conditions in which the manner of equipment attachment can contribute to lowering the level of vibrations in the carbody at the resonance frequency of bending. This action will trigger the emergence of the geometric filtering phenomenon of the excitations due to the track vertical irregularities, which makes the vibrations regime of the carbody visibly changed, depending on velocity. A reference is made here both for the modification of the level of vibrations in the carbody and also of the vibration modes that dominate the carbody response.

In terms of the influence of the mass of the elastically suspended equipment, the results herein show that its increase will lead to a similar action for the level of vibrations in the carbody in all its reference points at the 'low' bending frequency and a different one for the 'high' frequency.

Ultimately, the level of vibrations in the carbody can be reduced at both resonance frequencies of bending if an appropriate selection of the damping degree is made in the equipment attachment system to the carbody.

Manuscript received by Editorial Board, October 22, 2015; final version, February 21, 2016.

\section{REFERENCES}

[1] Pombo J., Ambrósio J.: An alternative method to include track irregularities in railway vehicle dynamic analyses, Nonlinear Dynamics, 2012, Vol. 68, Iss. 1-2, pp. 161-176. 
[2] Sebeşan I., Mazilu T.: Vibraţiile vehiculelor feroviare (Vibrations of the railway vehicles), MatrixRom, Bucureşti, 2010, (In Romanian).

[3] Zheng X., Zolotas A.C., Goodall R.M.: Modeling of flexible-bodied railway vehicles for vibration suppression, ICSE, Coventry, UK, Sep. 2006.

[4] Nie Y.Z., Zeng J., Li F.S.: Research on resonance vibration simulation method of highspeed railway vehicle carbody, International Industrial Informatics and Computer Engineering Conference (IIICEC 2015), pp. 1117-1121.

[5] Cheli F., Corradi R.: On rail vehicle vibrations induced by track unevenness: Analysis of the excitation mechanism, Journal of Sound and Vibration, Vol. 330, 2011, pp. 3744-3765.

[6] Dumitriu M.: On the critical points of vertical vibration in a railway vehicle, Archive of Mechanical Engineering, Vol. LXI, Number 4, 2014, pp. 609-625.

[7] Carlbom P.: Carbody and Passengers in Rail Vehicle Dynamics, Doctoral Thesis, Division of Railway Technology, Department of Vehicle Engineering, Royal Institute of Technology (KTH), Stockholm, Sweden, 2000.

[8] Tomioka T., Takigami T., Suzuki Y.: Numerical analysis of three-dimensional flexural vibration of railway vehicle car body, Vehicle System Dynamics, Vol. 44, Supplement, 2006, pp. 272-285.

[9] Diana G., Cheli F., Collina A., Corradi R., Melzi S.: The development of a numerical model for railway vehicles comfort assessment through comparison with experimental measurements, Vehicle System Dynamics, Vol. 38, No. 3, 2002, pp. 165-183.

[10] UIC 513 R: Guidelines for evaluating passenger comfort in relation to vibration in railway vehicle, International Union of Railways, 1994.

[11] ENV 12299: Railway applications ride comfort for passengers measurement and evaluation, 1997.

[12] Wu P.B., Xue S.H., Yang C.H.: Dynamic response of high-speed passenger car based on flexible carbody model. Journal of Traffic Transportation Engineering, Vol. 5, 2005, pp. 5-8.

[13] Zeng J., Luo R.: Vibration analysis of railway passenger car systems by considering flexible carbody effect. Journal of the China Railway Society, Vol. 29, Iss. 6, 2007, pp. 19-25.

[14] Zhou J., Goodall R., Ren L., Zhang H.: Influences of car body vertical flexibility on ride quality of passenger railway vehicles, Proceedings of the Institution of Mechanical Engineers, Part F: Journal of Rail and Rapid Transit, Vol. 223, 2009, pp. 461-471.

[15] Shi H.L., Luo R., Wu P.B., Zeng J., Guo J.Y.: Application of DVA theory in vibration reduction of carbody with suspended equipment for high-speed EMU, Science China Technological Sciences, Vol. 57, 2014, No. 7, pp. 1425-1438.

[16] Shi H.L., Luo R., Wu P.B., Zeng J., Guo J.Y.: Influence of equipment excitation on flexible carbody vibration of EMU, Journal of Modern Transportion, Vol. 22, Iss. 4, 2014, pp. 195205.

[17] Luo G., Zeng J., Wang Q.: Identifying the relationship between suspension parameters of underframe equipment and carbody modal frequency, Journal of Modern Transportion, Vol. 22, Iss. 4, 2014, pp. 206-213.

[18] Gong D., Zhou J.S., Sun W.J.: On the resonant vibration of a flexible railway car body and its suppression with a dynamic vibration absorber, Journal of Vibration and Control, Vol. 19, Iss. 5, 2012, pp. 649-657.

[19] Wu H.C., Wu P.B.: Effect of equipment suspension stiffness on riding quality, Journal Noise Vibration Control, Vol. 32, Iss. 8, 2012, pp. 73-77.

[20] Sun W., Gong D., Zhou J., Zhao Y.: Influences of suspended equipment under car body on highspeed train ride quality, Procedia Engineering 16, 2011, pp. 812-817.

[21] Mazilu T.: Vibraţii (Vibrations), MatrixRom, Bucureşti, 2012, (In Romanian).

[22] Dumitriu M.: Geometric filtering effect of vertical vibrations of railway vehicles, Analele Universităţii “Eftimie Murgu” Resiţa, no. 1, 2012, pp. 48-61. 
[23] Dumitriu M.: Considerations on the geometric filtering effect of the bounce and pitch movements in railway vehicles, Annals of Faculty Engineering Hunedoara - International Journal of Engineering, Tome XII, Fascicule 3, 2014, pp. 155-164.

\section{Wpływ wyposażenia zamontowanego w nadwoziu wagonu na charakterystyki drgań pionowych pojazdu szynowego kolei szybkobieżnych}

\section{Streszczenie}

Wyposażenie zamontowane na podwoziu pudła wagonu kolejowego stanowi krytyczny składnik pojazdu gdy chodzi o komfort jazdy. Powodem jest jego znaczna masa, zdolna w istotny sposób wpływać na drgania pojazdu. W artykule badano wpływ wyposażenia na tryb drgań pionowych nadwozia wagonu kolei szybkobieżnych. Za podstawę przyjęto częstotliwościowe funkcje przyspieszenia wyznaczone w trzech punktach odniesienia - w środku pojazdu i ponad wózkami zwrotnymi. Funkcje te zostały wyznaczone na podstawie symulacji numerycznych opracowanych dla sprzężonego sprężysto-sztywnego modelu o siedmiu stopniach swobody. Otrzymane wyniki z reguły potwierdzają, że sposób zamontowania wyposażenia (sztywne lub sprężyste), wraz $\mathrm{z}$ warunkami prędkości jazdy, mają wpływ na poziom wibracji w wybranych w punktach odniesienia na częstotliwości rezonansowej w symetrycznym trybie zgięciowym. Pokazano także jak masa wyposażenia i stopień tłumienia w systemie jego zawieszenia wpływają na poziom wibracji nadwozia. 